\title{
A smart Warehouse 4.0 approach for the pallet management using machine vision and Internet of Things (IoT): A real industrial case study
}

\author{
Vukićević, A. ${ }^{a}$, Mladineo, M. ${ }^{b}$, Banduka, N. ${ }^{\mathrm{a}, \mathrm{b}}$, Mačužić, I. ${ }^{\mathrm{a},{ }^{*}}$ \\ aFaculty of Engineering, University of Kragujevac, Kragujevac, Serbia \\ ${ }^{b}$ Faculty of Electrical Engineering, Mechanical Engineering and Naval Architecture, University of Split, Split, Croatia
}

\begin{abstract}
A B S T R A C T
Printing companies are commonly SMEs with high flow of materials, which management could be significantly improved through the digitalization. In this study we propose a smart Warehouse 4.0 solution by using QR code, open-source software tools for machine vision and conventional surveillance equipment. Although there have been concerns regarding the usage of $\mathrm{QR}$ in logistics, it has shown to be suitable for the particular use-case as pallets are static in the inter-warehouse. The reliability of reading of QR codes was achieved by using multiple IP cameras, so that sub-optimal view angle or light reflection is compensated with alternative views. Since surveillance technology and machine vision are constantly evolving and becoming more affordable, we report that more attention needs to be invested into their adaptation to fit the needs and budgets of SMEs, which are the industrial cornerstone in the most developed countries. The demo of proposed solution is available on the public repository https://github.com/ArsoVukicevic/PalletManagement.
\end{abstract}

\author{
ARTICLE INFO \\ Keywords: \\ Smart manufacturing; \\ SME; \\ Industry 4.0; \\ Logistics 4.0; \\ Warehousing 4.0; \\ Pallet management; \\ Machine vision; \\ Internet of Things (IoT); \\ QR code \\ *Corresponding author:
ivanm@kg.ac.rs \\ (Mačužić, I.) \\ Article history: \\ Received 30 May 2020 \\ Revised 15 September 2021 \\ Accepted 17 September 2021

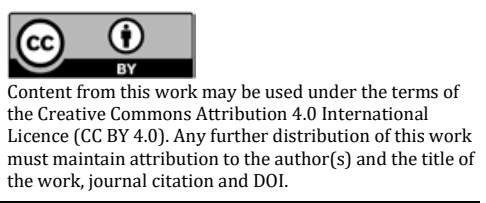

\section{References}

[1] Roy, D., Carrano, A.L., Pazour, J.A., Gupta, A. (2016). Cost-effective pallet management strategies, Transportation Research Part E: Logistics and Transportation Review, Vol. 93, 358-371, doi: 10.1016/j.tre.2016.06.005.

[2] Costantino, N., Dotoli, M., Falagario, M., Fanti, M.P., Mangini, A.M. (2012). A model for supply management of agile manufacturing supply chains, International Journal of Production Economics, Vol. 135, No. 1, 451-457, doi: 10.1016/i.ijpe.2011.08.021.

[3] Kagermann, H., Wahlster, W., Helbig, J. (2013). Recommendations for implementing the strategic initiative Industrie 4.0, Heilmeyer und Sernau, Berlin, Germany.

[4] Jayaraman, V., Ross, A.D., Agarwal, A. (2008). Role of information technology and collaboration in reverse logistics supply chains, International Journal of Logistics Research and Applications, Vol. 11, No. 6, 409-425, doi. $10.1080 / 13675560701694499$.

[5] Tang, C.S., Veelenturf, L.P. (2019). The strategic role of logistics in the Industry 4.0 era, Transportation Research Part E: Logistics and Transportation Review, Vol. 129, 1-11, doi: 10.1016/j.tre.2019.06.004.

[6] Barreto, L., Amaral, A., Pereira, T. (2017). Industry 4.0 implications in logistics: An overview, Procedia Manufac- 
turing, Vol. 13, 1245-1252, doi: 10.1016/j.promfg.2017.09.045.

[7] Lyu, Z., Lin, P., Guo, D., Huang, G.Q. (2020). Towards zero-warehousing smart manufacturing from zeroinventory just-in-time production, Robotics and Computer-Integrated Manufacturing, Vol. 64, Article No. 101932, doi: $10.1016 /$ i.rcim.2020.101932.

[8] Urso, O., Chiacchio, F., Compagno, L., D’Urso, D. (2020). An RFID application for the process mapping automation, Procedia Manufacturing, Vol. 42, 8-15, doi: 10.1016/j.promfg.2020.02.017.

[9] Żywicki, K., Rewers, P. (2020). A simulation-based approach to study the influence of different production flows on manufacturing of customized products, Advances in Production Engineering \& Management, Vol. 15, No. 4, 467-480, doi: 10.14743/apem2020.4.379.

[10] Sarı, T., Güleș, H.K., Yiğitol, B. (2020). Awareness and readiness of Industry 4.0: The case of Turkish manufacturing industry, Advances in Production Engineering \& Management, Vol. 15, No. 1, 57-68, doi: 10.14743/apem2020. 1.349 .

[11] Focardi, R., Luccio, F.L., Wahsheh, H.A.M. (2019). Usable security for QR code, Journal of Information Secuity and Applications, Vol. 48, Article No. 102369, doi: 10.1016/i.jisa.2019.102369.

[12] Gjeldum, N., Mladineo, M., Crnjac, M., Veza, I., Aljinovic, A. (2018). Performance analysis of the RFID system for optimal design of the intelligent assembly line in the learning factory, Procedia Manufacturing, Vol. 23, 63-68, doi: 10.1016/i.promfg.2018.03.162.

[13] Arumugam, D.D., Engels, D.W. (2008). Impacts of RF radiation on the human body in a passive RFID environment, In: Proceedings of 2008 IEEE Antennas and Propagation Society International Symposium, San Diego USA, 14, doi: 10.1109/APS.2008.4619663.

[14] Lin, J.C. (2006). A new IEEE standard for safety levels with respect to human exposure to radio-frequency radiation, IEEE Antennas and Propagation Magazine, Vol. 48, No. 1, 157-159, doi: 10.1109/MAP.2006.1645601.

[15] TURCK Gmbh \& Co. KG. BL ident $®$ RFID System Planning and Engineering, from https://www.turck.de/attachment/100000268.pdf, accessed September 15, 2019.

[16] Qian, J.-P., Yang, X.-T., Wu, X.-M., Zhao, L., Fan, B.-L., Xing, B. (2012). A traceability system incorporating 2D barcode and RFID technology for wheat flour mills, Computers and Electronics in Agriculture, Vol. 89, 76-85, doi: 10.1016/i.compag.2012.08.004.

[17] Liang, K., Chen, X., He, R., Li, J., Okinda, C., Han, D., Shen, M. (2019). Development and parameter optimization of automatic separation and identification equipment for grain tracing systems based on grain tracers with QR codes, Computers and Electronics in Agriculture, Vol. 162, 709-718, doi: 10.1016/j.compag.2019.04.039.

[18] Liu, K., Bi, Y., Liu, D. (2020). Internet of things based acquisition system of industrial intelligent bar code for smart city applications, Computer Communications, Vol. 150, 325-333, doi: 10.1016/i.comcom.2019.11.044.

[19] Moreira, A., Silva, F.J.G., Correia, A.I., Pereira, T., Ferreira, L.P., de Almeida, F. (2018). Cost reduction and quality improvements in the printing industry, Procedia Manufacturing, Vol. 17, 623-630, doi: 10.1016/j.promfg.2018. 10.107.

[20] Gaganis, C., Pasiouras, F., Voulgari, F. (2019). Culture, business environment and SMEs' profitability: Evidence from european countries, Economic Modelling, Vol. 78, 275-292, doi: 10.1016/i.econmod.2018.09.023.

[21] Vivanco Florido, J.S., Gonzalez Adame, M., Oropeza Tagle M.A. (2015). Financial strategies, the professional development of employers and performance of sme's (Aguascalientes case), Procedia - Social and Behavioral Sciences, Vol. 174, 768-775, doi. 10.1016/i.sbspro.2015.01.613.

[22] TimeStation. Turn any smartphone or tablet into a cloud-based time \& attendance system, from http://www.mytimestation.com, accessed September 12, 2021.

[23] Cognex. Industrial cameras, from https://www.cognex.com/ accessed September 12, 2021.

[24] Vukicevic, A.M., Milic, V., Zabotti, A., Hocevar, A., De Lucia, O., Filippou, G., Frangi, A.F., Tzioufas, A., De Vita, S., Filipovic, N. (2019). Radiomics-based assessment of primary Sjögren's syndrome from salivary gland ultrasonography images, IEEE Journal of Biomedical and Health Informatics, Vol. 24, No. 3, 835-843. doi: 10.1109/ JBHI.2019.2923773.

[25] Ho, C.-C., Wang, H.-P., Chiao, Y.-C. (2021). Deep learning based defect inspetion in TFT-LCD rib depth detection, Measurement: Sensors, Vol. 18, Article No. 100198, doi: 10.1016/i.measen.2021.100198.

[26] ISO/IEC 18004:2015, Information technology - Automatic identification and data capture techniques - QR code bar code symbology specification, from https://www.iso.org/standard/62021.html, accessed November 12, 2021.

[27] Kiurski, J.S., Marić, B.B., Oros, I.B., Kecić, V.S. (2017). The ecodesign practice in Serbian printing industry, Journal of Cleaner Production, Vol. 149, 1200-1209, doi: 10.1016/j.jclepro.2017.02.193.

[28] Visintin, F., (2012). Providing integrated solutions in the professional printing industry: The case of Océ, Computers in Industry, Vol. 63, No. 4, 379-388, doi: 10.1016/i.compind.2012.02.010.

[29] Vafaeenezhad, T., Tavakkoli-Moghaddam, R., Cheikhrouhou, N. (2019). Multi-objective mathematical modeling for sustainable supply chain management in the paper industry, Computers \& Industrial Engineering, Vol. 135, 1092-1102, doi: 10.1016/i.cie.2019.05.027.

[30] Huin, S.F., Luong, L.H.S., Abhary, K. (2003). Knowledge-based tool for planning of enterprise resources in ASEAN SMEs, Robotics and Computer-Integrated Manufacturing, Vol. 19, No. 5, 409-414, doi: 10.1016/S0736-5845(02) 00033-9.

[31] Erbe, H.-H. (2003). Manufacturing with low cost automation, IFAC Proceedings Volumes, Vol. 36, No. 7, 95-100, doi: 10.1016/S1474-6670(17)35813-5.

[32] Kopacek, P. (1992). 'Low-cost' factory automation, IFAC Proceedings Volumes, Vol. 25, No. 25, 27-33, doi: 10.1016/S1474-6670(17)49574-7.

[33] Github, Warehouse 4.0 solution for the pallet management in SMEs with QR-code, machine vision and IP cameras: A use-case from the printing industry, from https://github.com/ArsoVukicevic/PalletManagement, accessed September 12, 2021. 
[34] Qian, J., Du, X., Zhang, B., Fan, B., Yang, X. (2017). Optimization of QR code readability in movement state using response surface methodology for implementing continuous chain traceability, Computers and Electronics in Agriculture, Vol. 139, 56-64, doi: 10.1016/i.compag.2017.05.009.

[35] Sengupta, J., Ruj, S., Das Bit, S. (2020). A comprehensive survey on attacks, security issues and blockchain solutions for IoT and IIoT, Journal of Network and Computer Applications, Vol. 149, Article No. 102481, doi: 10.1016/i.jnca.2019.102481. 


\section{APEM}

Advances in Production Engineering \& Management Letnik 16 | Številka 3 | September 2021 | Strani 297-306 https://doi.org/10.14743/apem2021.3.401
ISSN 1854-6250

Spletna stran: apem-journal.org Izvirni znanstveni članek

\title{
Pameten pristop Skladišče 4.0 za upravljanje palet $\mathrm{z}$ uporabo strojnega vida in interneta stvari (IoT): Industrijska študija primera
}

\author{
Vukićević, A. ${ }^{a}$, Mladineo, M. $^{b}$, Banduka, N. ${ }^{a, b}$, Mačužić, I. ${ }^{a}{ }^{,}$ \\ aFaculty of Engineering, University of Kragujevac, Kragujevac, Serbia \\ ${ }^{\mathrm{b}}$ Faculty of Electrical Engineering, Mechanical Engineering and Naval Architecture, University of Split, Split, Croatia
}

\begin{abstract}
POVZETEK
Tiskarska podjetja so običajno mala in srednja velika podjetja (SME) z velikim pretokom materiala, katerega upravljanje bi lahko z digitalizacijo bistveno izboljšali. V tej študiji predlagamo pametno rešitev Skladišče $4.0 \mathrm{z}$ uporabo QR kode, odprtokodnih programskih orodij za strojni vid in konvencionalne opreme za nadzor. Čeprav so obstajali pomisleki glede uporabe QR v logistiki, se je izkazalo, da je v nekaterih primerih za uporabo primerna, saj so palete $\mathrm{v}$ medfaznem skladišču statične. Zanesljivost branja QR kod je bila dosežena $\mathrm{z}$ uporabo več IP kamer, tako da se neoptimalen zorni kot ali odboj svetlobe kompenzira $\mathrm{z}$ alternativnimi posnetki. Ker se tehnologija nadzora in strojni vid nenehno razvijata in postajata cenovno dostopnejša, ugotavljamo, da je treba več pozornosti vložiti v prilagajanje potrebam in proračunom SME, ki so industrijski temelj v najbolj razvitih državah. Prikaz predlagane rešitve je na voljo na: https://github.com/ArsoVukicevic/PalletManagement.
\end{abstract}

\section{PODATKI O ČLANKU}

Ključne besede: Pametna proizvodnja; SME;

Industrija 4.0 ;

Logistika 4.0;

Skladiščenje 4.0;

Upravljanje palet;

Strojni vid;

Internet stvari (IoT);

QR koda

* Kontaktna oseba: ivanm@kg.ac.rs

(Mačužić, I.)

Zgodovina članka:

Prejet 30. maja 2020

Popravljen 15. septembra 2021

Sprejet 17. septembra 2021

\section{(i)}

Content from this work may be used under the terms of the Creative Commons Attribution 4.0 International Licence (CC BY 4.0). Any further distribution of this work must maintain attribution to the author(s) and the title of the work, journal citation and DOI. 